\title{
Above-Ground Net Primary Production for Elymus lanceolatus and Hesperostipa curtiseta After a Single Defoliation Event
}

\author{
A. Pantel, ${ }^{1}$ J. T. Romo, ${ }^{2}$ and Y. Bai ${ }^{2}$ \\ Authors are ${ }^{1}$ Former Graduate Student and ${ }^{2}$ Professors, Department of Plant Sciences, 51 Campus Drive, University of Saskatchewan, Saskatoon, \\ Saskatchewan, Canada S7N 5 A8.
}

\begin{abstract}
Above-ground net primary production (ANPP) of northern wheatgrass (Elymus lanceolatus [Scribn. \& J. G. Sm.] Gould) and western porcupine grass (Hesperostipa curtiseta [Hitchc.] Barkworth) was determined after defoliation to a $7.5 \mathrm{~cm}$ stubble height on five landform elements in the Northern Mixed Prairie that had been ungrazed for $>25$ yr. Landform elements included north aspect-concave slopes, north aspect-convex slopes, south aspect-concave slopes, south aspect-convex slopes, and level uplands. ANPP was determined for 2 yr after defoliating plots once in May, June, July, August, September, October, November, or April. Northern wheatgrass and western porcupine grass ANPP varied among landform elements $(P<0.01)$, but not with the month of defoliation $\times$ landform element interaction $(P \geq 0.22)$. Month of defoliation did not influence ANPP of northern wheatgrass $(P \geq 0.69)$, but that of western porcupine grass was reduced by August and September defoliations $(P<0.01)$. ANPP of both grasses was insensitive to landform element in terms of defoliation responses. Northern wheatgrass ANPP was not responsive to temporal aspects of a single defoliation. With the exception of August and September defoliations, western porcupine grass also was insensitive to a single defoliation in different months. Land managers should consider rest (1 yr nongrazing) following grazing of western porcupine grass in August or September, whereas responses to defoliation in different months suggest northern wheatgrass can be grazed annually.
\end{abstract}

\section{Resumen}

Se determinó la producción primaria aérea anual neta (PPAN) de Elymus lanceolatus [Scribn. \& J. G. Sm.] Gould y Hesperostipa curtiseta [Hitchc.] Barkworth luego de una defoliación hasta 7,5 cm de altura residual en cinco elementos del paisaje en la Pradera Mixta de América del Norte que había sido excluida del pastoreo por $>25$ años. Los elementos del paisaje incluyeron laderas cóncavas con exposición hacia el norte, laderas convexas con la misma exposición, laderas cóncavas con exposición al sur, laderas convexas con la misma exposición, y áreas planas elevadas. La PPAN se determinó durante dos años posteriores a un evento único de defoliación en mayo, junio, julio, agosto, septiembre, octubre, noviembre, o abril. La PPAN de E. lanceolatus y H. curtiseta varió entre elementos del paisaje $(P<0.01)$, pero no fue influenciada por la interacción entre el mes de defoliación y el elemento del paisaje $(P \geq 0.22)$. El mes de defoliación no influenció la PPAN de E. lanceolatus $(P \geq 0.69)$, pero la PPAN de $H$. curtiseta se redujo con las defoliaciones de agosto y septiembre $(P<0.01)$. La PPAN de ambas especies fue insensible a la ubicación en el paisaje en términos de respuestas a la defoliación. La PPAN de E. lanceolatus no respondió a los aspectos temporales de una única defoliación. Excepto las defoliaciones de agosto y septiembre, H. curtiseta también fue insensible a una única defoliación en meses distintos. H. curtiseta debería recibir descanso (1 año sin pastoreo) luego de ser pastoreada en agosto o septiembre, mientras que las respuestas de E. lanceolatus a la defoliación en diferentes meses sugiere que esta especie puede ser pastoreada todos los años.

Key Words: ANPP, Canadian Prairies, grazing management, landform elements, landforms, landscapes, Northern Mixed Prairie, northern wheatgrass, western porcupine grass

\section{INTRODUCTION}

Landscapes in the Northern Mixed Prairie are composed of many landform elements with species composition and production potential of plants varying among aspects (Ayyad and Dix 1964; Redmann 1975; Butler and Goetz 1986) and topographic positions (Klemmendson 1964; Redmann 1975). Plant community composition, the microenvironment, and resource availability also differ with slope degree, slope aspect,

Funding for this research was provided by a research grant to J.T.R. and Y.B. from the Saskatchewan Agriculture Development Fund (Project-20000272).

Correspondence: J. T. Romo, Dept of Plant Sciences, 51 Campus Drive, University of Saskatchewan, Saskatoon, Saskatchewan, Canada S7N 5A8. Email: Jim.Romo@usask.ca

Manuscript received 8 February 2010; manuscript accepted 23 January 2011. and landform element (Ayyad and Dix 1964; Baines 1973; Lieffers and Larkin-Lieffers 1987; Pennock et al. 1987; Braun 2005). Variable characteristics in the physical environment among slope aspects, slope degree, and landform elements can influence the rate at which plants recover their production following defoliation. Plants do indeed respond differently to grazing in different topographic positions (Archer and Tieszen 1986).

The importance of resting plants and allowing them to recover after grazing was highlighted by Voisin (1959), but few studies have addressed the time needed to regain their production potential. Resting plants after grazing might be more critical than grazing per se (Snyman 1998). Furthermore, simulation models indicate resting plants after grazing is integral to sustaining long-term productivity on rangelands 
(Müller et al. 2007). Information on the recovery of plants and their productivity after grazing is basic and essential if periods of rest are to be included in grazing strategies (Caldwell 1984). Three $\mathrm{yr}$ to $8 \mathrm{yr}$ elapse before bluebunch wheatgrass (Pseudoroegneria spicata [Pursh] A. Löve) regains vigor following defoliation in mountain grasslands (Mueggler 1975). In contrast, western wheatgrass (Pascopyrum smithii [Rydb.] A. Löve) recovers from a single, heavy defoliation event within 14 mo to 26 mo (Trlica et al. 1977).

The abundance of northern wheatgrass (Elymus lanceolatus [Scribn. \& J. G. Sm.] Gould) and western porcupine grass (Hesperostipa curtiseta [Hitchc.] Barkworth) varies with slope and aspect in the Northern Mixed Prairie (Ayyad and Dix 1964). Even though the caespitose western porcupine grass is common and one of the most abundant native grasses in the Northern Mixed Prairie of Canada (Coupland 1950, 1961), the authors are aware of no defoliation studies on this grass. Northern wheatgrass, a rhizomatous species, is sensitive to single or multiple defoliation events (Zhang and Romo 1994; Kowalenko and Romo 1998a, 1998b). Because plant production varies among aspects, topographic positions, and times of defoliation, we hypothesized that above-ground net primary production (ANPP) of northern wheatgrass and western porcupine grass would vary with the time of defoliation and landform elements. The purpose of this study was to determine the production response of northern wheatgrass and western porcupine grass to a single defoliation made during the grazing season (from April to November) in relation to landform elements in the Northern Mixed Prairie of south-central Saskatchewan. Northern wheatgrass and western porcupine grass were chosen for study because they are two of the most important native forage species (Coupland 1950, 1961) throughout much of the Northern Mixed Prairie in Canada.

\section{MATERIALS AND METHODS}

\section{Study Site}

Research was conducted from 2001 through 2004 on the Missouri Coteau in the Coteau Hills landscape of the Mixed Grassland Ecoregion (Acton et al. 1998), about $20 \mathrm{~km}$ south of Macrorie, Saskatchewan, Canada (lat $51^{\circ} 14^{\prime} \mathrm{N}$, long $107^{\circ} 15^{\prime} \mathrm{W}$, elevation $720 \mathrm{~m}$ ). The study site lies in the Dark Brown Soil Zone and soils are Calcareous Dark Brown Chernozems of the Weyburn Association with their origin being glacial till (Ellis et al. 1970). Topography of this landscape is hummocky, strongly sloping to moderately rolling with $10 \%$ to $15 \%$ slope. The range site is classified as Loamy (Abouguendia 1990). The study site had not been grazed for more than $25 \mathrm{yr}$ and was in excellent range condition.

At Rock Point, Saskatchewan, about $10 \mathrm{~km}$ from the study site, temperatures average $3.5^{\circ} \mathrm{C}$ annually, and range from monthly means of $-14.0^{\circ} \mathrm{C}$ in January to $18.6^{\circ} \mathrm{C}$ in July (Fig. 1; Environment Canada 2008). Annual temperatures in 2001 through 2004 were within $1^{\circ} \mathrm{C}$ of the long-term average. Yearly precipitation at Rock Point, Saskatchewan averages $377 \mathrm{~mm}$, of which $49 \%$ is received in May, June, and July. Annual precipitation totaled $206 \mathrm{~mm}$ in $2001,392 \mathrm{~mm}$ in 2002, $271 \mathrm{~mm}$ in 2003, and $401 \mathrm{~mm}$ in 2004. Precipitation

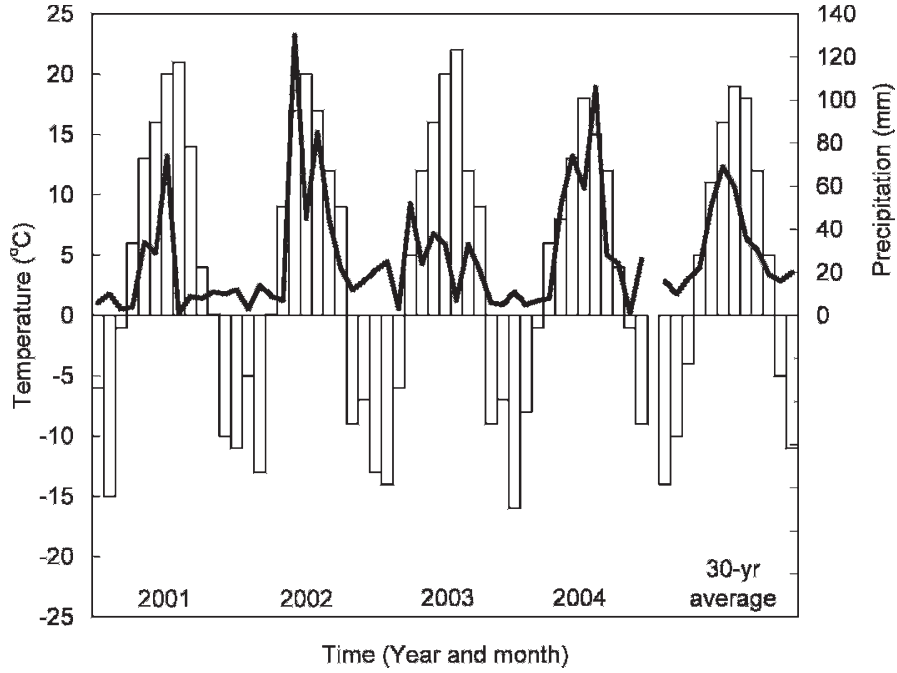

Figure 1. Average monthly temperatures, long-term average temperatures (1974-2004), monthly precipitation, and long-term average precipitation at Rock Point, Saskatchewan, Canada (Environment Canada 2008).

received in May through July totaled $137 \mathrm{~mm}, 182 \mathrm{~mm}, 95 \mathrm{~mm}$, and $184 \mathrm{~mm}$ in 2001, 2002, 2003, and 2004, respectively.

\section{Experimental Design}

The effects of landform element and month of defoliation on ANPP of northern wheatgrass and western porcupine grass were examined at two sites within an area of about $1 \mathrm{~km}^{2}$. Within each site, landform elements were arranged in a completely randomized, split-plot design with 8 mo of defoliation and a nondefoliated control with four replications. The experiment was conducted over 2 yr (Years 1 and 2): from 2001 to 2003 at Site 1 and from 2002 to 2004 at Site 2. Five landform elements were selected according to slope aspect and shape, and except for the level upland landform element, all were at the backslope position (Pennock et al. 1987). The landform elements included level uplands, north aspectconcave slopes, north aspect-convex slopes, south aspectconcave slopes, and south aspect-convex slopes. An $18 \mathrm{~m} \times$ $20 \mathrm{~m}$ block was established on each replicate landform element and the block was separated into nine, $2 \mathrm{~m} \times 20 \mathrm{~m}$ plots oriented from the top to the bottom of the slope. The plots defoliated in April, May, June, July, August, September, October, or November, and the nondefoliated control were randomly assigned to plots in each replicate landform element.

Plots were subjected to a single defoliation by mowing with a sickle mower to a height of $7.5 \mathrm{~cm}$ in their assigned month of treatment. The $7.5 \mathrm{~cm}$ defoliation height was chosen to simulate one intense defoliation event. Plots were defoliated from mid-May to mid-November 2001 and in mid-April 2002 at Site 1 and over the same period in 2002-2003 at Site 2. The months of defoliation were selected because rangeland in the study area can be grazed during this period. All mowed plant material was removed from the plots.

Each $2 \mathrm{~m} \times 20 \mathrm{~m}$ plot was subdivided into four subsections that were $2 \mathrm{~m}$ wide and $5 \mathrm{~m}$ long. Green above-ground standing crop of northern wheatgrass and western porcupine grass was sampled by clipping at ground level in one $50 \mathrm{~cm} \times$ 
Table 1. Cover and composition of northern wheatgrass, western porcupine grass, and plains rough fescue on five landform elements.

\begin{tabular}{|c|c|c|c|c|c|}
\hline \multirow[b]{2}{*}{ Species } & \multicolumn{5}{|c|}{ Aspect and landform element } \\
\hline & $\begin{array}{l}\text { North aspect- } \\
\text { concave slope }\end{array}$ & $\begin{array}{l}\text { North aspect- } \\
\text { convex slope }\end{array}$ & $\begin{array}{l}\text { South aspect- } \\
\text { concave slope }\end{array}$ & $\begin{array}{l}\text { South aspect- } \\
\text { convex slope }\end{array}$ & $\begin{array}{l}\text { Level } \\
\text { upland }\end{array}$ \\
\hline Northern wheatgrass & $5 a b c^{1}$ & $7 a b$ & $\begin{array}{c}\text { ver }(\%)-- \\
2 c\end{array}$ & $3 b c$ & $9 a$ \\
\hline Western porcupine grass & $9 a$ & $5 a$ & $11 \mathrm{a}$ & $13 a$ & $11 \mathrm{a}$ \\
\hline Plains rough fescue & $20 a$ & $22 a$ & $10 b$ & $2 c$ & $5 b c$ \\
\hline Northern wheatgrass & $8 b$ & $12 b$ & $5 b$ & $6 b$ & $25 a$ \\
\hline Western porcupine grass & $15 b c$ & $9 c$ & $21 a b$ & $27 a$ & $30 a$ \\
\hline Plains rough fescue & $37 a$ & $40 a$ & $22 b$ & $5 c$ & $11 b c$ \\
\hline
\end{tabular}

${ }^{1}$ Within species, means with the same letter are not significantly different $(P \geq 0.05)$.

$50 \mathrm{~cm}$ quadrat randomly located in each of the four subsections in June, July, and August in 2002 and 2003 at Site 1 and in the same months in 2003 and 2004 at Site 2. The samples from the four subsections were pooled within species to give an estimate for $1 \mathrm{~m}^{2}$. The locations of harvested quadrats were avoided in subsequent samplings. Samples were dried at $80^{\circ} \mathrm{C}$ for $48 \mathrm{~h}$ and weighed.

The amount of green above-ground standing crop removed by defoliation in May, June, and July was estimated by clipping plants at ground level after defoliating plots. This yield was then compared with the green above-ground standing crop of plants from the nondefoliated control as a percentage, which was then subtracted from $100 \%$ to estimate the percentage of green above-ground standing crop removed by defoliation.

Soil water content was determined at the same time that green above-ground standing crop was sampled. Soil cores, $2 \mathrm{~cm}$ in diameter, were removed from the $0-15 \mathrm{~cm}$ depth at three random locations in each replicate plot, weighed, dried at $80^{\circ} \mathrm{C}$ for $48 \mathrm{~h}$, and reweighed. Soil water content was calculated on a dry mass basis. Soil water content was then averaged for all samples taken in June and July. Average soil water content in June and July was used because most plant growth occurs in these months.

Composition of the plant communities in nondefoliated control plots on the five landform elements was characterized by estimating canopy cover of every species in the four replicates at Site 1 in July 2001 and at Site 2 in July 2002. Twenty, $20 \mathrm{~cm} \times 50 \mathrm{~cm}$ quadrats were placed at 1 -m intervals from the top to the bottom of the slope in the plots, and canopy cover of plant species was recorded (Daubenmire 1959).

\section{Data Analyses}

ANPP for northern wheatgrass and western porcupine was estimated by unconstrained summation of positive increments of green above-ground standing crop between successive months of clipping within Years 1 and 2 after defoliation (Singh et al. 1975). Specifically, ANPP was determined by summing green above-ground standing crop in June, plus positive increments in green above-ground standing crop from June to July, and from July to August. The production dynamics are poorly understood for northern wheatgrass and western porcupine grass. Therefore, the percentage of ANPP produced by July was determined by dividing the ANPP produced by July by the total ANPP.
Defoliation effects on ANPP and soil water content were tested within Years 1 and 2 with a split-split plot analysis of variance (ANOVA) in a randomized-complete block design with four replicates (Hoshmand 2006). Sites were considered whole or main plots, landform elements were treated as the split-plots or subplots, and months of defoliation were the splitsplit plots or subsubplots. Hoshmand (2006) described the ANOVA and the appropriate error terms for the split-split plot ANOVA. Means of ANPP in the defoliated plots were compared with the nondefoliated control as preplanned comparisons using Fischer's Protected LSD (Petersen 1985) when the ANOVA indicated significant differences among months of defoliation $(P \leq 0.05)$. When ANPP and soil water content varied significantly $(P \leq 0.05)$ between sites, means were compared within sites using Fischer's Protected LSD. In all tests, statistical significance was assumed at $P \leq 0.05$.

\section{RESULTS}

\section{Plant Species Composition on the Five Landform Elements}

Twenty-two graminoid species and 51 forb species were recorded in the plots on the five landform elements (data not shown). Plant communities at both sites were dominated by $\mathrm{C}_{3}$ plants with $99 \%$ of plant community composition being contributed by this functional group and the remainder by $\mathrm{C}_{4}$ plants. Western porcupine grass and plains rough fescue (Festuca hallii [Vasey] Piper) codominated south aspectconcave slopes, western porcupine grass dominated south aspect-convex slopes, level uplands were codominated by western porcupine grass and northern wheatgrass, and plains rough fescue dominated north aspects (Table 1). Cover $(P=0.01)$ and the percent composition $(P<0.01)$ for northern wheatgrass varied significantly among landform elements (Table 1); its cover was greatest on the north aspects and the level uplands, whereas composition was greatest on the level uplands. Western porcupine grass cover did not vary significantly between sites or among landform elements $(P \geq 0.13)$, averaging $10 \%(\mathrm{SE} \pm 1.0)$, but composition of the grass was greatest $(P<0.01)$ on the southerly aspects and level uplands.

The total canopy cover of $60 \%$ for all plants at Site 2 was significantly greater than the $42 \%$ total canopy cover at Site 1 $(P<0.01$, SE \pm 3.4$)$. Cover of forbs and that of other graminoids also was greater at Site 2 than Site 1 (both 

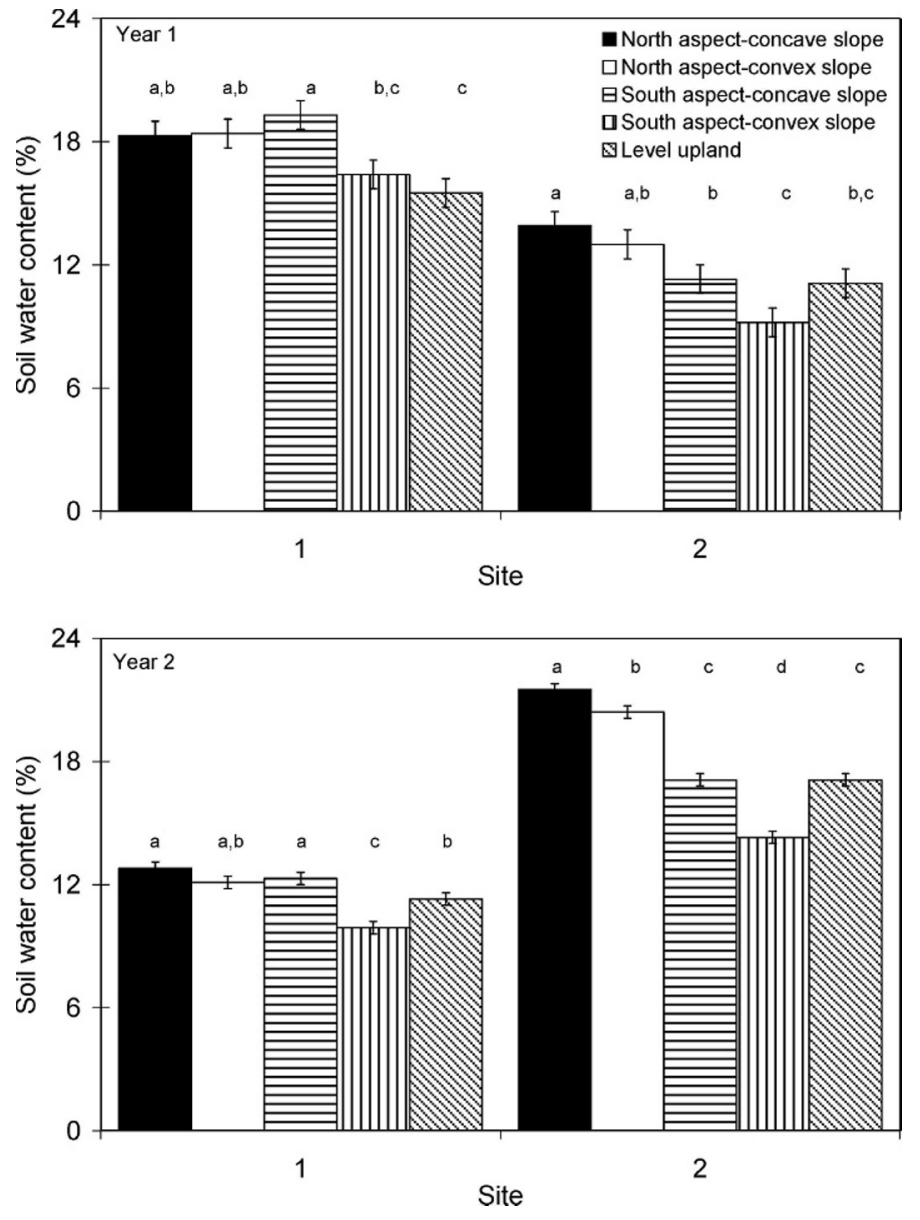

Figure 2. Soil water content in the $0-15 \mathrm{~cm}$ depth in June and July during the first and second years after defoliation on five landform elements. Within years and sites, means with the same letter are not significantly different $(P \geq 0.05)$. Vertical lines are standard errors for the means determined from analysis of variance.

$P<0.01)$. Forb cover at Sites 1 and 2 averaged $7 \%$ and $15 \%$ $(\mathrm{SE} \pm 1.2)$, respectively; cover of other graminoids averaged $18 \%$ and $30 \%(\mathrm{SE} \pm 2.4)$, respectively, for Sites 1 and 2 .

\section{Green Above-ground Standing Crop Removed by Defoliation}

The percentage of green above-ground standing crop removed from northern wheatgrass averaged $58 \%(\mathrm{SE} \pm 2.4)$ and was not different between sites $(P=0.07)$, among landform elements $(P=0.41)$ and months of defoliation $(P=0.10)$, or their interactions $(P \geq 0.10)$. For western porcupine grass, the percentage of green above-ground standing crop removed by defoliation did not vary significantly between sites $(P=0.32)$, among landform elements $(P=0.31)$ and months of defoliation $(P=0.08)$, as well as interactions $(P \geq 0.18)$ and averaged $51 \%$ $(\mathrm{SE} \pm 2.6)$.

\section{Soil Water Content}

Site and landform element interacted to influence soil water content in Year $1(P=0.04)$ and Year $2(P<0.01$; Fig. 2). Except for the south aspect-concave slopes at Site 2, soil water content tended to be greatest on the concave slopes and the northerly aspects, and least on the south aspect-convex slopes

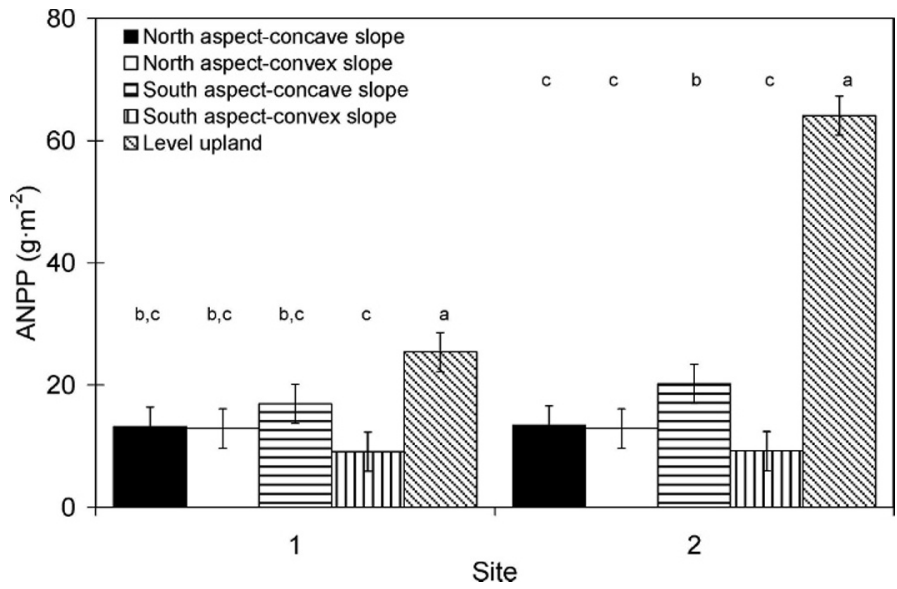

Figure 3. Above-ground net primary production (ANPP) for northern wheatgrass in the first year after being defoliated on five landform elements. Within sites, means with the same letter are not significantly different $(P \geq 0.05)$. Vertical lines are standard errors for the means determined from analysis of variance.

and the level uplands in Year 1. Soil water content in Year 2 tended to be greatest on the north aspect-concave slopes and least on the south aspect-convex slopes.

\section{Northern Wheatgrass ANPP}

In Years 1 and 2, the percentage of northern wheatgrass ANPP produced by July in nondefoliated controls did not vary significantly between sites $(P=0.77$ and $P=0.80)$, among landform elements $(P=0.66$ and $P=0.67)$, and the interaction between site and landform element was not significant $(P=0.55$ and $P=0.15)$. Northern wheatgrass produced $80 \%$ $(\mathrm{SE} \pm 4.1)$ and $78 \%(\mathrm{SE} \pm 4.2)$ of the ANPP by July of Years 1 and 2, respectively.

Defoliating northern wheatgrass had no significant effect on ANPP in Year $1(P=0.69)$ and Year $2(P=0.99)$. The interaction of month of defoliation and landform elements had no significant effect on ANPP in Year $1(P=0.99)$ and Year $2(P=0.93)$. Site and landform element interactively influenced ANPP in Year $1(P=0.02$; Fig. 3). Among landform elements in Year 1, ANPP varied by 2.8-fold at Site 1 and 7fold at Site 2; ANPP was greatest on the level uplands and least on the south aspect-convex slopes at both sites. In Year 2, ANPP varied by 4.9 -fold among landform elements $(P<0.01$; Fig. 4), and was greatest on the level uplands and least on the north and south aspects with convex slopes.

\section{Western Porcupine Grass ANPP}

The percentage of ANPP for western porcupine grass in nondefoliated controls produced by July of Year 1 and Year 2 did not vary significantly between sites $(P=0.34$ and $P=0.27)$, among landform elements $(P=0.86$ and $P=0.95)$, and the interaction between site and landform element $(P=0.54$ and $P=0.41)$. Of the ANPP, $81 \%(\mathrm{SE} \pm 4.5)$ and $76 \%(\mathrm{SE} \pm 4.4)$ was produced by July in Years 1 and 2, respectively.

In Year 1, ANPP for western porcupine grass was significantly $(P<0.01)$ reduced by defoliating plants in August and September (Fig. 5). ANPP in Year 1 also varied with the 


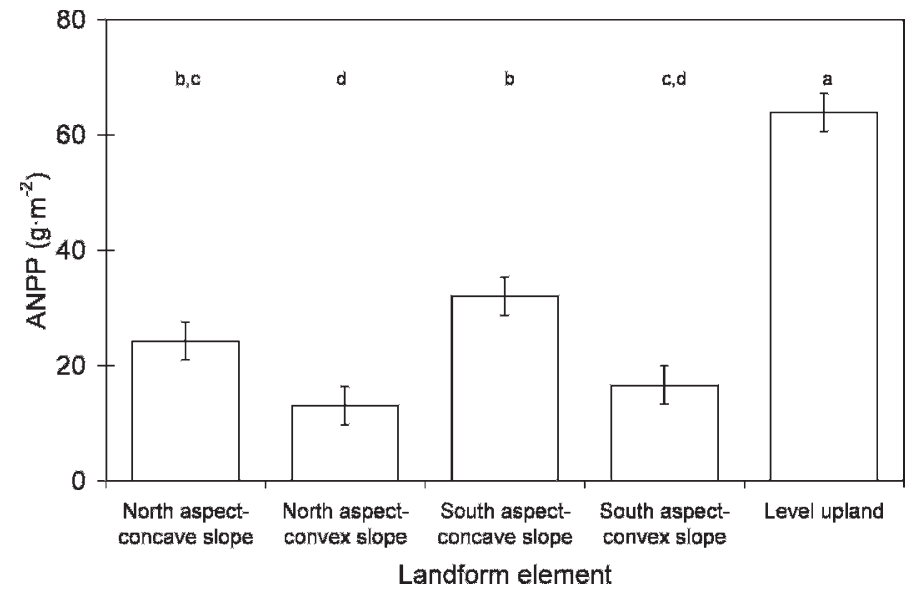

Figure 4. Above-ground net primary production (ANPP) for northern wheatgrass on five landform elements in the second year after being defoliated. Means with the same letter are not significantly different $(P \geq 0.05)$. Vertical lines are standard errors for the means determined from analysis of variance.

interacting effects of site and landform element $(P=0.03$; Fig. 6), and it was greatest on the south aspect-convex slopes and least on the north aspect-convex slopes. Among landform elements, ANPP varied by 2.5 -fold at Site 1 and 11.4 -fold at Site 2 in Year 1. In Year 2, ANPP varied significantly $(P<0.01)$ among landform elements, and was greatest on the south aspect-concave slopes and least on the north aspects (Fig. 7). The interaction of month of defoliation and landform element had no significant effect on ANPP in Year $1(P=0.22)$ and Year $2(P=0.60)$.

\section{DISCUSSION}

Contrary to our hypothesis, ANPP for northern wheatgrass and western porcupine grass was not significantly influenced by the interacting effects of landform element and month of defolia-

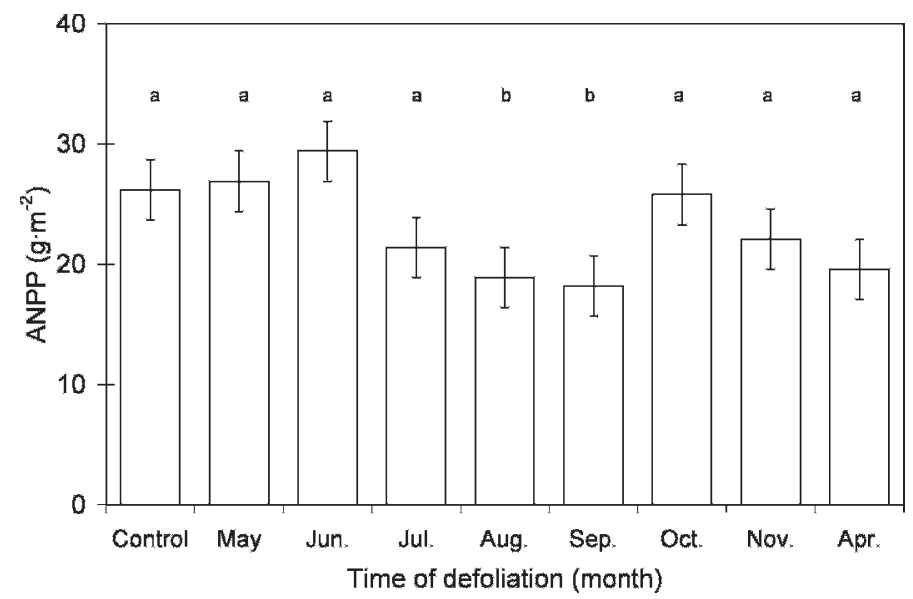

Figure 5. Above-ground net primary production (ANPP) for western porcupine grass during the first year after being defoliated in eight different months. Means with the same letter are not significantly different from the nondefoliated control $(P \geq 0.05)$. Vertical lines are standard errors for the means determined from analysis of variance.

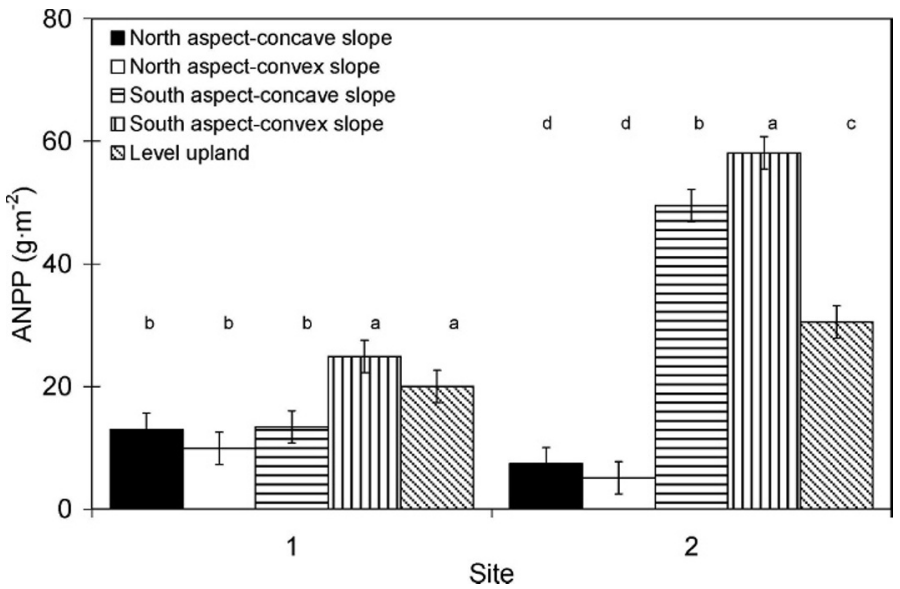

Figure 6. Above-ground net primary production (ANPP) for western porcupine grass in the first year after being defoliated on five landform elements. Within sites, means with the same letter are not significantly different $(P \geq 0.05)$. Vertical lines are standard errors for the means determined from analysis of variance.

tion. Instead, conditions on the five landform elements had significant effects on ANPP of northern wheatgrass whereas the month of defoliation did not. Likewise, ANPP for western porcupine grass varied significantly among landform elements; however, ANPP varied among months of defoliation in the first, but not in the second growing season, after defoliation.

We hypothesized that the ANPP response to the month of defoliation would change with landform elements because the microenvironment, resource availability, and plant species composition vary among the five landform elements. Furthermore, because of differences in the microenvironment among landform elements (Ayyad and Dix 1964; Lieffers and LarkinLieffers 1987), phenology of plants might differ among landform elements (Jackson 1966; Redmann 1975; Aragon et al. 2007; Iverson et al. 2009), and plant responses to defoliation usually change with phenology (Buwai and Trlica 1977; Trlica et al. 1977; Harrison and Romo 1994; Romo and

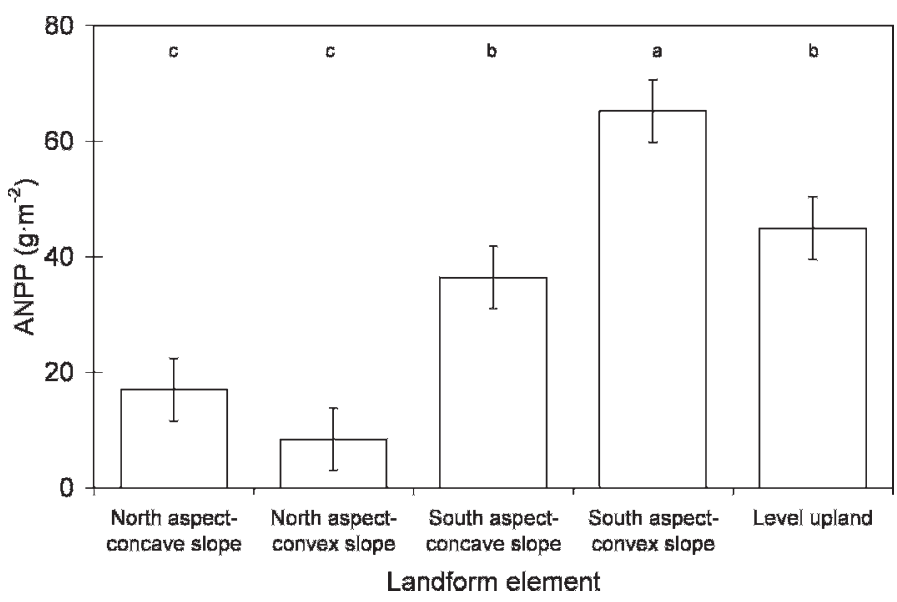

Figure 7. Above-ground net primary production (ANPP) for western porcupine grass on five landform elements in the second year after being defoliated. Means with the same letter are not significantly different $(P \geq 0.05)$. Vertical lines are standard errors for the means determined from analysis of variance. 
Harrison 1999). Although plant phenology was not measured in our study, differences among landform elements in the phenology of both grasses at the time of defoliation likely were minor because ANPP was not related to the interacting influences of landform elements and month of defoliation. In the Shortgrass Prairie, some plant species respond to the interacting effects of long-term grazing and topographic position with grazing effects minimized by favorable growing conditions and amplified by unfavorable growing conditions (Milchunas et al. 1989). Greater intensities and (or) frequencies of defoliation, defoliation in several years, more intense intraspecific competition, and resource limitations for growth would possibly produce ANPP responses to the interacting effects of defoliation and landform element, similar to that observed on different range sites (Holderman and Goetz 1981; Patton et al. 2007) and landforms (Archer and Tieszen 1986).

The significant effect of landform element on northern wheatgrass ANPP suggests resource availability on the five landform elements placed greater constraints on production than did month of defoliation and the interaction of landform element and month of defoliation. Others (Biondini et al. 1998; Heitschmidt et al. 1999) have also concluded that environmental conditions constrain production more than grazing in the semiarid Northern Mixed Prairie. Variability in ANPP among the five landform elements was also expected because abundance of northern wheatgrass varied by 6 -fold. The lack of response to month of defoliation contrasts with decreased production for northern wheatgrass following a single defoliation on a clayey range site in the Brown Soil Zone of Saskatchewan (Kowalenko and Romo 1998b). Greater herbage removal, removal of litter, a different range site, and different associated species in the study of Kowalenko and Romo (1998b) all might have factored into divergent responses of northern wheatgrass to defoliation compared with the present study. Removing litter reduces plant production in the Brown Soil Zone of the Canadian Prairies (Willms et al. 1986), but primary production is unaffected by amounts of litter in Stipa-Agropyron grasslands in the Dark Brown Soil Zone of Saskatchewan, presumably because the effectiveness of precipitation is greater than in the Brown Soil Zone (Pylypec and Romo 2003).

Derner and Briske (2001) suggested rhizomatous species might occupy microsites in which soils have greater concentrations of carbon and nitrogen. Together, greater resource availability and efficiency of allocating resources during regrowth (Caldwell et al. 1981; Li and Redmann 1992a, $1992 b)$ might have enabled northern wheatgrass to recuperate ANPP the year following defoliation. This recovery of ANPP contrasts with that observed by Zhang and Romo (1994) wherein repeated defoliation at 2- or 6-wk intervals during the growing season on range with a history of heavy grazing reduced production by northern wheatgrass. Together, the responses observed in the present study and that of Zhang and Romo (1994) are interpreted as suggesting that frequency of defoliation might be more important than timing of defoliation in terms of production by northern wheatgrass, and past grazing history might also influence plant production after grazing. In addition, defoliating all plant species likely reduced the competitive ability of neighbors, which in turn can diminish deleterious effects of herbage removal (Mueggler 1975; Archer and Detling 1984).
ANPP for northern wheatgrass varied significantly between the two sites even though they were in close proximity. Disparity in ANPP between sites might have been caused by the yearly variation in precipitation amounts and timing as well as temperatures. Interannual variation in production in the Northern Mixed Prairie is primarily controlled by the amount and timing of precipitation (Smoliak 1986; Biondini and Manske 1996; Heitschmidt et al. 1999; Eneboe et al. 2002; Heitschmidt et al. 2005; Derner and Hart 2007). Other factors not measured also might have influenced production of northern wheatgrass at the two sites. For example, cold stress in the winter reduces production by northern wheatgrass the following growing season (Kowalenko and Romo 1998a).

Except for a decrease in the first year after defoliation in August or September, western porcupine grass ANPP was not affected significantly by herbage removal. Reduced ANPP following defoliation in August and September might have been caused by less production of new tissue and (or) increased senescence of tillers and leaves relative to the other months of defoliation. Defoliating thin needlegrass (Nassella tenuis [Phil.] Barkworth) late in the growing season increases tiller senescence (Becker et al. 1997) as does defoliating crested wheatgrass (Agropyron desertorum [Fisch. ex Link] Schultes), and bluebunch wheatgrass after internode elongation (Gold and Caldwell 1989). Alternatively, the ratio of new tissue to senescent tissue might have been greater in the other months of defoliation as compared with the August and September defoliations because herbage removal can enhance production of new tissue and delay senescence (McNaughton et al. 1983; Nowak and Caldwell 1984; Gold and Caldwell 1989; Becker et al. 1997).

Reduced ANPP for western porcupine grass in the August and September defoliations also could have been caused by the combined effects of limited precipitation late in the growing season, competitive interactions, and inefficient acquisition and allocation of resources to above-ground growth. In the Northern Mixed Prairie of Saskatchewan, soil water content in late summer is limited because of infrequent and small precipitation events (Colberg and Romo 2003). Most of the ANPP for western porcupine grass occurs by July, and thus the potential for additional growth usually is limited when defoliated in late summer. Plants defoliated in the spring or early summer have opportunities to regrow and regain vigor that growing season, whereas production is interrupted by defoliation in late summer with reduced ANPP in the next growing season. On the other hand, plants can complete their growth and little or no green growth is removed by defoliation when plants are dormant in autumn or early spring. Plants that recover faster and are more competitive following defoliation can exploit resources above and below ground more efficiently and gain a competitive advantage (Mueggler 1975; Caldwell 1984; Thomas 1984). Less efficient acquisition and allocation of resources such as carbon and nitrogen to foliage developing after defoliation appears to increase sensitivity of plants to herbage removal (Caldwell et al. 1981). In semiarid environments, nutrient pools in the soil are smaller beneath caespitose grasses than rhizomatous grasses (Derner and Briske 2001), which in turn can limit plant production after defoliation. Regardless, the specific cause(s) for reduced ANPP of western porcupine grass after defoliation in August and September 
cannot be identified in this study. Reduced ANPP after the August and September defoliations does, however, merit attention because grazing in late summer often is perceived as having minimal influence on plant growth. In a similar vein, no significant change in western porcupine grass ANPP after defoliation early in the growing season challenges the notion of low tolerance of herbage removal at that time.

\section{IMPLICATIONS}

Responses in ANPP for northern wheatgrass and western porcupine grass must be interpreted with the proviso that plants were subjected to a single defoliation event of moderate intensity on sites that had not been grazed for $>25 \mathrm{yr}$. Production responses of these grasses well might be different if plants are defoliated multiple times (Trlica et al. 1977; Zhang and Romo 1994; Busso and Richards 1995). More intense and (or) more frequent defoliation might suppress production longer than that observed here because defoliation history plays important roles in determining ANPP (Mullahey et al. 1991; Turner et al. 1993; Tate et al. 1994). Given that ANPP for northern wheatgrass in Years 1 and 2 was not statistically different from the nondefoliated controls on all landform elements after all months of defoliation suggests this grass can be grazed annually, provided there is one defoliation event per year. In contrast, multiple defoliations in a year would appear to reduce production by northern wheatgrass (Zhang and Romo 1994). Reduced ANPP for western porcupine grass following defoliation in August and September, however, indicates susceptibility to defoliation and the need for rest or deferment the year after grazing in these months.

Recovery of ANPP after defoliation of northern wheatgrass and western porcupine grass does not vary significantly among landform elements; however, the actual amount of ANPP does. Taken together, if western porcupine grass or northern wheatgrass are key species, management decisions can be based on their ANPP responses to grazing on multiple landform elements because the month of defoliation and landform element did not interactively influence when ANPP had recovered following a single defoliation event.

\section{LITERATURE CITED}

AвouguendiA, Z. M. 1990. A practical guide to planning for management and improvement of Saskatchewan rangeland: range plan development. Regina, Saskatchewan, Canada: New Pasture and Grazing Technologies Project. $52 \mathrm{p}$.

Acton, D. F., G. A. Padbury, and C. T. Stushnoff. 1998. The ecoregions of Saskatchewan. Regina, Saskatchewan, Canada: University of Regina, Canadian Plains Research Center. 205 p.

Aragon, C. F., M. J. Albert, L. Gimenez-Benavides, A. L. Luzuriagas, and A. Escudero. 2007. Environmental scales on the reproduction of a gypsophyte: a hierarchical approach. Annals of Botany 99:519-527.

Archer, S., And J. K. Detling. 1984. The effects of defoliation and competition on regrowth of tillers of two North American Mixed-Grass Prairie graminoids. Oikos 43:351-357.

Archer, S., and L. L. Tieszen. 1986. Plant responses to defoliation: hierarchical considerations, In: 0. Gudmundsson [ED.]. Grazing research at northern latitudes. New York, NY, USA: Plenum Publishing. p. 45-59.
Ayyad, M. A., And R. L. Dix. 1964. An analysis of a vegetation-environmental complex on prairie slopes in Saskatchewan. Ecological Monographs $34: 421-442$.

BAINES, G. B. K. 1973. Plant distributions on a Saskatchewan prairie. Vegetatio 28:99-123.

Becker, G. F., C. A. Busso, T. Montani, A. L. Orchansky, R. E. Brevedan, M. A. Burgos, and A. C. Flemmer. 1997. Effects of defoliating Stipa tenuis and Piptochaetium napostaense at different phenological stages: tiller demography and growth. Journal of Arid Environments 35:251-268.

BiondinI, M. E., And L. Manske. 1996. Grazing frequency and ecosystem processes in a Northern Mixed Prairie, USA. Ecological Applications 6:239-256.

Biondini, M. E., B. D. Patton, and P. E. Nyren. 1998. Grazing intensity and ecosystem processes in a Northern Mixed-Grass Prairie, USA. Ecological Applications 8:469-479.

Braun, M. D. 2005. Spatial and temporal variation in greenhouse gas flux as affected by mowing on grassland of hummocky terrain in Saskatchewan [thesis]. Saskatoon, Saskatchewan, Canada: University of Saskatchewan. 125 p.

Busso, C. A., and J. H. Richards. 1995. Drought and clipping effects on tiller demography and growth of two tussock grasses in Utah. Journal of Arid Environments 29:239-251.

Butler, J., And H. Goetz. 1986. Vegetation and soil-landscape relationships in the North Dakota Badlands. American Midland Naturalist 116:378-386.

Buwal, M., AND M. J. TrLica. 1977. Multiple defoliation effects on herbage yield, vigor, and total nonstructural carbohydrates of five range species. Journal of Range Management 30:164-171.

Caldwell, M. M. 1984. Plant requirements for prudent grazing. In: Developing strategies for rangeland management. A report prepared by the committee on developing strategies of rangeland management. National Research Council/ National Academy of Sciences. Boulder, CO, USA: Westview Press. p. $117-152$.

Caldwell, M. M., J. H. Richards, D. A. Johnson, R. S. Nowak, and R. S. Dzurec. 1981. Coping with herbivory: photosynthetic capacity and resource allocation in two semiarid Agropyron bunchgrasses. Oecologia 50:14-24.

Colberg, T. J., And J. T. Romo. 2003. Clubmoss effects on plant water status and standing crop. Journal of Range Management 56:489-495.

Coupland, R. T. 1950. Ecology of Mixed Prairie in Canada. Ecological Monographs 20:271-315.

Coupland, R. T. 1961. A reconsideration of grassland classification in the Northern Great Plains of North America. Journal of Ecology 49:135-167.

DAUBENMIRE, R. 1959. A canopy-coverage method of vegetational analysis. Northwest Science 33:43-66.

Derner, J. D., and D. D. Briske. 2001. Below-ground carbon and nitrogen accumulation in perennial grasses: a comparison of caespitose and rhizomatous growth forms. Plant and Soil 237:117-127.

Derner, J. D., and R. H. Hart. 2007. Grazing-induced modifications to peak standing crop in Northern Mixed-Grass Prairie. Rangeland Ecology \& Management 60:270-276.

Ellis, J. G., D. F. Acton, and H. C. Moss. 1970. The soils of the Rosetown map area (720), Saskatchewan. Saskatoon, Saskatchewan, Canada: Saskatchewan Institute of Pedology Publication 202. $146 p$.

Eneboe, E. J., B. F. Sowell, R. K. Heitschmidt, M. G. Karl, and M. R. Haferkamp. 2002. Drought and grazing: IV. Blue grama and western wheatgrass. Journal of Range Management 55:197-203.

Environment Canada, Atmospheric Environmental Service. 2008. Canada climate normals. (1971-2000). Available at: http://climate.weatheroffice.ec.gc.ca/ climateData/monthlydata_e.html?timeframe $=3 \&$ Prov $=C A \&$ Station $I D=3328 \&$ Year=1996\&Month=1\&Day=3. Accessed 1 March 2008.

Gold, W. G., and M. M. Caldwell. 1989. The effects of spatial pattern of defoliation on regrowth of a tussock grass. Oecologia 80:289-296.

HarRison, T., And J. T. Romo. 1994. Regrowth of smooth bromegrass (Bromus inermis Leyss.) following defoliation. Canadian Journal of Plant Science 74:531-537.

Heitschmidt, R. K., M. R. Haferkamp, M. G. Karl, and A. L. Hild. 1999. Drought and grazing: I. Effects on quantity of forage produced. Journal of Range Management 52:440-446. 
Heitschmidt, R. K., K. D. Klement, and M. R. Haferkamp. 2005. Interactive effects of drought and grazing on Northern Great Plains rangelands. Rangeland Ecology \& Management 58:11-19.

Holderman, C. A., and H. Goetz. 1981. Response of western North Dakota Mixed Prairie to intensive clipping and five stages of development. Journal of Range Management 34:188-193.

Hoshmand, A. R. 2006. Design of experiments for agriculture and the natural sciences. Nashua, NH, USA: Chapman and Hall. 437 p.

Iverson, M., K. A. Brathen, N. G. Yoccoz, and R. A. Ims. 2009. Predictors of plant phenology in a diverse high-latitude alpine landscape: growth forms and topography. Journal of Vegetation Science 20:903-915.

JaCkSON, M. T. 1966. Effects of microclimate on spring flowering phenology. Ecology 47:407-415.

KLEMMENDSON, J. 0. 1964. Topofunction of soils and vegetation in a range landform. In: M. Stelley [ED.]. Forage physiology and soil-plant relationships. Madison, WI, USA: American Society of Agronomy. Special Publication No. 5. p. 176-189.

Kowalenko, B. L., AND J. T. Romo. 1998a. Defoliation and cold-hardiness of northern wheatgrass. Journal of Range Management 51:63-68.

KowalenKo, B. L., AND J. T. Romo. 1998b. Regrowth and rest requirements of northern wheatgrass following defoliation. Journal of Range Management $51: 73-78$

LI, Y. S., And R. E. Redmann. 1992a. Nitrogen budget of Agropyron dasystachyum in Canadian Mixed Prairie. American Midland Naturalist 128:61-71.

LI, Y. S., AND R. E. Redmann. 1992b. Nitrogen budget and ${ }^{15} \mathrm{~N}$ translocation in a perennial wheatgrass. Functional Ecology 6:221-225.

LiefFers, V. J., And P. A. Larkin-LiefFers. 1987. Slope, aspect, and slope position as factors controlling grassland communities in the coulees of the Oldman River, Alberta. Canadian Journal of Botany 65:1371-1378.

McNaughton, S. J., L. L. Wallace, and M. B. Coughenour. 1983. Plant adaptations in an ecosystem context: effects of defoliation, nitrogen, and water on growth of an African $\mathrm{C}_{4}$ sedge. Ecology 64:307-318.

Milchunas, D. G., W. K. Lauenroth, P. L. Chapman, and M. K. Kazempour. 1989. Effects of grazing, topography, and precipitation on the structure of a semiarid grassland. Vegetatio 80:11-23.

MueggleR, W. F. 1975. Rate and pattern of vigor recovery in Idaho fescue and bluebunch wheatgrass. Journal of Range Management 28:188-204.

Mullahey, J. J., S. S. Waller, and L. E. Moser. 1991. Defoliation effects on yield and bud and tiller numbers of two sandhills grasses. Journal of Range Management 44:241-245.

Müller, B., K. Frank, and C. Wissel. 2007. Relevance of rest periods in nonequilibrium rangeland ecosystems-a modeling analysis. Agricultural Systems 92:295-317.

Nowak, R. S., ANd M. M. Caldwell. 1984. A test of compensatory photosynthesis in the field: implications for herbivory tolerance. Oecologia 61:311-318.
Patton, B. D., X. Dong, P. E. Nyren, and A. Nyren. 2007. Effects of grazing intensity, precipitation, and temperature on forage production. Rangeland Ecology \& Management 60:656-665.

Pennock, D. J., B. J. Zebarth, and E. Dejong. 1987. Landform classification and soil distribution in hummocky terrain, Saskatchewan, Canada. Geoderma 40:297-315

Petersen, R. G. 1985. Design and analysis of experiments. New York, NY, USA: Marcel Dekker. $429 \mathrm{p}$

Pylypec, B., And J. T. Romo. 2003. Long-term effects of burning Festuca and StipaAgropyron grasslands. Journal of Range Management 56:640-645.

Redmann, R. E. 1975. Production ecology of grassland plant communities in western North Dakota. Ecological Monographs 45:83-106.

Romo, J. T., AND T. HARRISON. 1999. Regrowth of crested wheatgrass (Agropyron cristatum [L.] Gaertn.) following defoliation. Canadian Journal of Plant Science 79:557-563.

Singh, J. S., W. K. Lauenroth, and R. K. Steinhorst. 1975. Review and assessment of various techniques for estimating net aerial primary production in grasslands from harvest data. Botanical Review 41:181-232.

Smoliak, S. 1986. Influence of climatic conditions on production of StipaBouteloua Prairie over a 50-year period. Journal of Range Management 39:100-103

Snyman, H. A. 1998. Dynamics and sustainable utilization of rangeland ecosystems in arid and semi-arid climates of southern Africa. Journal of Arid Environments 39:645-666.

Tate, K. W., R. L. Gilleen, R. L. Mitchell, and R. L. Stevens. 1994. Effect of defoliation intensity on regrowth of tallgrass prairie. Journal of Range Management 47:38-42.

THomas, H. 1984. Effects of drought on growth and competitive ability of perennial ryegrass and white clover. Journal of Applied Ecology 21:591-602.

Trlica, M. J., M. Buwal, and J. W. Menke. 1977. Effects of rest following defoliations on the recovery of several range plants. Journal of Range Management 30:21-27.

Turner, C. L., T. R. Seastedt, and M. I. Dyer. 1993. Maximization of aboveground grassland production: the role of defoliation frequency, intensity, and history. Ecological Applications 3:175-188.

VoIsIN, A. 1959. Grass productivity. Reprinted in 1988, Island Press Edition. Covelow, CA, USA: Island Press. 353 p.

Willms, W. D., S. Smoliak, and A. W. Balley. 1986. Herbage production following litter removal on Alberta native grasslands. Journal of Range Management $39: 536-540$

ZHANG, J., AND J. T. Romo. 1994. Defoliation of a northern wheatgrass community: above- and below-ground phytomass productivity. Journal of Range Management 47:279-284. 